(Continued from page 154.)

Males are more numerous, or at least more are captured, than females, probably being readier to take wing and in consequence falling into the net in sweeping. The species prefers sedgy meadow-lands and swales on sandy soil occasionally flooded by rains or freshets and perpetually moist. The bulk of my specimens were taken on a boggy swamp which had been filled in with sand, and on which water stood more or less of the time.

\section{Paratettix Bol.}

Paratettix Bolivar 1887. Essai,-Ann. Soc. ent. Belg., xxxi, 195, I7o.

4. Paratettix cucullatus Burm. Figs. 4, 4a.

Tetrix cucullata Burm., 1838 . Handb. d. ent., ii, $65^{8}$.

Tettix cucullata Burm. Scudder, 475.

$\begin{array}{cccl}\text { " } & \text { " } & \text { Scudd. } & \text { Thomas, 185. } \\ \text { " cucullatus } & \text { “" } & \text { Fernald, 47. } \\ \text { “ } & \text { " } & \text { Burm. } & \text { Bolivar, 259, } 266 . \\ \text { " } & \text { " } & \text { "“ } & \text { Morse, 54, 107. }\end{array}$

This species was unknown to Bolivar who left it in Tettix, being misled perhaps by Scudder's statement that it most resembles $T$. granulatus and failing to appreciate properly the characters given in Scudder's description, which he quotes. It belongs, without doubt, as shown by the structure of the vertex and spiculate character of pulvilli of proximal joint of hind tarsi, in Bolivar's genus Paratettix and seems to be fairly well described under the name of $P$. mexicanus Sauss.
Description, etc.-It is easily recognized by the form of the vertex [Figs. 4, 4a]. From above this appears about equal in width to one of the large and prominent eyes, and does not project in advance of them; its front margin is slightly hollowed, the concavity being divided by the mid-carina which projects a little. In profile the frontal costa is slightly sinuate opposite the eyes and strongly protuberant opposite the antennae. The crown of the head is channeled longitudinally on either side of the mid-carina, the sulci being stopped abruptly opposite the hinder portion of the eyes by a pair of transverse, sometimes slightly oblique, ridges. This character is found in several species of this genus and in this species appears at a very early stage, showing distinctly in specimens $3 \mathrm{~mm}$. in length. The body is less compressed than in the preceding species, being, in truth, depressed rather than compressed. The pronotum is advanced upon the head to the eyes, and the median carina is obsolete on the anterior portion; the posterior process extends $2-3 \mathrm{~mm}$. beyond the hind femora, exceeded by the wings, and is very constant in proportions.

Measurements of New England specimens are as follows:-

Total length. Pron. Pron.> Hind fem. Wings $>$ Pron. of II. $-13.5 \quad 9.5-11.20 \quad-2.5 \quad-5-1.5$ o $13.5^{-1} 5.5$ II. $-13 . \quad 2.5-3 . \quad$ I. -2 .

In color and ornamentation it is one of the least variable of our species, resembling closely its surroundings in tint and texture, varying from mottled yellowish-gray almost to dull black.

Habits, etc.-In. distribution it appears to be somewhat southern, and very local. It prefers the immediate margin of lakes and streams, often alighting on the water when disturbed, and swimming well. I have taken it in 
but three localities in New England, but it probably occurs over the whole of Connecticut and in central Massachusetts. A nymph in Mr. Scudder's collection is labeled "Vicinity of Boston."

My specimens are from Connecticut as follows :-

Canaan, Aug. $18, \mathrm{I}$ ㅇ.

Thompson, July ${ }_{3}, 6 \delta, 3$ ㅇ, scarce. Aug. 4-9, 7 $\&$, very scarce.

New Haven, Aug 29, abundant; males, females and young in several stages, some scarcely more than $2 \mathrm{~mm}$. in length being secured.

The Thompson and Canaan specimens were found on the sandy mud of a lake-shore, and were yellowish-gray; the others on the margin of a little stream strewn with fragments of blackened wood and other waste and were very dark.

I have taken it at Ithaca, N. Y., also, where it is common along the stony margins of the creeks and exactly matches in tint the fragments of slategray shale on which it delights to sun itself, becoming in consequence, almost invisible on alighting.

It is one of the most active and alert of our species, taking wing readily and flying several feet, or even a rod or more. It is readily captured, however, by sweeping the net rapidly over its haunts.

\section{BATRACHIDEAE.}

4. Tettigidea Scudd. Fig. 5.

Tettigidea Scudder, I862. Mater. monog. Orth. N. A.,-Boston journ. nat. hist., vii, 476.
5. Tettigidea lateralis Say.

Acrydium laterale Say, i824. Amer. ent., i, Pl. 5 .

Acrydium laterale Say. Ent. N. A., Lec. ed., i, Io, 1859 .

Tetrix lateralis Harris, 187.

Tettigidea lateralis Say. Scudder, 477 .

$$
\text { " " Scudd. Thomas, } 187 \text {. }
$$$$
\text { " " } " \text { Say. Fernald, } 48 .
$$

“ " Scudd. Bolivar, 295,

298.

Tettigidea lateralis Say. Morse, 54, 107.

Measurements.

Total length. Pron. Pron $>$ Hind fem Wings $>$ Pron.

o II.5-I3. 9.8-II.5 $\quad .7-\mathrm{I} .5 \quad 7-5$

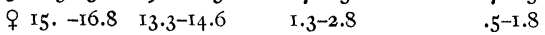

6. Tettigidea polymorpha Burm.

Tetrix polymorpha Burmeister, 1838 . Handbuch ii, 659 .

Tetrix parvipennis. Harris, 187.

Tettigidea polymorpha Burm. Scudder, 477 .

Tettigidea polymorpha scudd. Thomas, I88.

Tettigidea polymorpha Burm. Fernald, 48.

Tettigidea polymorpha Burm. Bolivar, 295, 297.

Tettigidea polymorpha Burm. Morse, 54, 107.

Measurements.

Total length. Pron. Pron. $>$ Hind fem. Wings $<$ Pron. on $8.4-\mathrm{II} .5$ 8. $-\mathrm{Ir} . \quad-\mathrm{r} .-+.5 \quad$ I.3-3.5 o II.5-I4. I0.4-I3. $\quad-\mathrm{I} .-+\mathrm{I}$.

The two New England members of this genus are readily distinguished from our other 'Tettiginae by the presence of twenty-two joints in the antennae (instead of $12-14$ ), and by the shape of the crown of the head, which has a lobe on each side encroaching upon the dorsal portion of the eye. 
The two forms differ only in the degree of development (or abortion) of wings and pronotum and for this reason are believed by some to be forms of one dimorphic species. For this reason I here treat them together.

Lateralis is distinguished from polymorpha by the presence of fully developed wings and usually by a somewhat longer pronotum. The variation in these structures and their relative proportions with regard to other parts of the body and to each other will be best observed in the measurements here given. I have one specimen, a $\delta$, in which the pronotum does not pass the hind femora but the wings extend $2.5 \mathrm{~mm}$. beyond it, thus being intermediate in character between the two forms. This specimen may be regarded as either a lateralis with unusually short pronotum, or a reversional polymorpha,-I am disposed to think that the former view is the more correct in this case, for the reason that the pronotum is of very variable length in both forms, and its apex is frequently twisted or distorted in one way or another, while the wings seem to be relatively quite constant in length.

While I am by no means convinced that lateralis + lateralis will not produce polymorpha, or polymorpha+ polymorpha will not produce lateralis (i. e., that the two forms are not one species) I have given each specific rank here for the reason that, whether they are distinct species or dimorphic forms of one, both names will be retained, as they properly should be, to distinguish them. And as they have hitherto been observed to mate true they may best be regarded for the present as incipient species.

The reasons pro and con may be summed up as follows, structural characters only being considered :-

Ist, in favor of specific distinctness-

They have been observed many times to mate true and not cross with each other.

Intermediate specimens are very scarce.

Both forms are tolerably common.

2nd, in favor of dimorphism-

Cases of reversion are common in other species of the family, with or without intermediate forms.

Cases of dimorphism are very common in other species of the family.

Variations in length of tegmina and wings are usually of little or no importance in other members of the family.

Variations in length of pronotum in this subfamily correspond to variations in length of tegmina in others.

Cases of reversion occur in this subfamily.

Cases of dimorphism occur in this subfamily.

In such cases the wings are usually shortest proportionally in specimens with the shortest pronota and vice versa.

Intermediate forms occur, having pronotum of one form and wings of the other.

Similar forms occur in other species of the genus.

In the short-winged form the end of the pronotum is especially subject to distortions of one sort or another. 
Specimens illustrative of the preceding statements have been examined in the preparation of this paper and with but one exception occur in my collection.

Bolivar makes use of the markings of the tegmina in his key to the species of this genus. Our forms usually have a white or flavescent spot near the apex of the tegmen, but in dry cabinet specimens this is not invariably present, either in lateralis or polymorpha.

Habits, etc.-Our members of this genus agree in habits with the species of Tettix, preferring moist, grassy and sedgy meadows, particularly on rather light soil. I have taken them in such situations in company with Tettix granulatus and $T$. ornatus, and even along roadside gutters on springy land, where the ground was moist and sandy. In New England polymorpha is about three times as common as lateralis. The sexes seem to be taken in about equal numbers except that where plentiful I have secured about twice as many $\delta$ as $q$ polymorpha.

Both forms probably occur throughout New England. I have specimens of polymorpha from Fryeburg and Norway, Me., Hanover and Keene, N. H. (C. M. Weed), Jackson, N. H., Brattleboro, Vt. (Mrs. J. B. Powers), Hartland, Vt. (C. M. Weed), Newport, Vt., Beverly, Wellesley and several towns in its vicinity, and Winchendon, Mass. (Also from Adams, but the specimen was afterward lost.) Canaan, North Haven, So. Kent, Stamford, and Thompson, Conn. The lateralis form
I have from Fryeburg, Me., Hanover, N. H. (C. M. Weed), Jay, Newport, and Stowe, Vt., Wellesley and Winchedon, Mass., and Block Id., R. I. Both forms were common in a meadow in Fryeburg, Me., on Aug 20, and I secured about 30 lateralis, 60 polymorpha and 20 young in a couple of hours. The young varied much in size, some being but one-quarter grown, others in the last stage. Two years later at the same time of the month I found the young rather more common than the adults, in several localities in Conn.

Both forms, though widely spread, are rarely found in considerable numbers. I have seldom taken over half a dozen at a time. They seem to be more plentiful in the central states than in New England. I have found dragging or sweeping the net closely over the ground in the localities frequented by them to be the most successful method of capture.

The American naturalist (1894, pp. $483-487$ ) contains an interesting account from the pen of Dr. J. L. Hancock, of observations on migratory flights of lateralis witnessed in Chicago, the insects being attracted to the electric lights in large numbers.

LIST.

Tetrigiae

I. Nomotettix.

I. cristatus Harr.

$\begin{array}{lll}.0 & \text { " } & \text { " type form. } \\ \text {.I } & \text { carinatus Scudd., var. }\end{array}$ 


\section{Tettix.}

2. ornatus Say.

$$
\begin{aligned}
& \text {.0 " " type"form. } \\
& \text {.I " } \text { " triangularis Scudd. }
\end{aligned}
$$

\section{Paratettix.}

4. cucullatus Burm.

\section{BATRACHIDEAE.}

\section{Tettigidea.}

5. lateralis Say.

6. polymorpha Burm.

[Tettix harrisii Packard,一Rep't. nat. hist. Maine, r86r, 375-376, is undescribed and consequently has no scientific standing.]

Errata.-I regret to say that several typographical errors in my "Preliminary List of the Acrididae of N.E." (Psyche, I894, pp. 102-108) need correction as follows :-

Page 105, G. II, should read "Scirtetica." " $\quad$ ro6, Sp. 33, " " " "atlanis."

" " G. I9, " " "Pezotettix."

" 108, col. I, line 4, " "Acyptera."

\section{POLYGAMY OF ACTIAS LUNA AND CALLOSAMIA PROMETHEA.}

On April 29th, 1894, a $\delta$ and $\&$ A. luna emerged in my box, and on that night mated, remaining in coitu until after ten o'clock the next day. On April zoth, the $q$ was put into a box prepared for egg-laying, and a newly emerged $q$ was put into the cage with the $\delta$. That night, between ten and eleven they were found in coitu, and so remained until after ten o'clock the next day. Both females laid many eggs, and both sets of eggs gave larvae on May 21 st and 22nd. The $\delta$ was kept for several days, but, as no other + emerged, was then let out at the window and flew away almost as vigorously as a freshly emerged moth.

In 1893 a o $C$. promethea, in a cage by an open window, attracted about forty $\delta \delta$ twenty of which were caught and put into the cage. At first they all flew up and down the netting, with great excitement and much vibration of the wings, then six of them seized the abdomen of the $q$ with their claspers, and struggled for possession, nor did the others lose their hold when one was successful. After fifteen minutes this $\delta$ was removed and put into another cage, when a second took his place almost immediately, and was left for twenty minutes, then was removed and put into the second cage. In less than ten minutes a third $\delta$ had mated with the $q$, was later removed, and a fourth took his place. This was repeated until seven $\delta \delta$ had mated with this one $q$.

Meanwhile these $\delta \delta$ not caught were flying up and down the outside of the cage and finally dropped dead with exertion and excitement. They were kept two days to be sure that they would not revive.

So many $\delta \delta$ were flying about the window that three cats spent an hour or more trying to catch them, and passers-by stopped to look.

When the seventh $\delta$ had been mated for an hour he was removed, and the $f$ taken outdoors and put on a low branch of an ash tree. There she attracted all the unmated $\delta \delta$ and an eighth paired with her. The others flew about the tree, until dark, when observations ceased.

Eggs laid by this $q$ hatched in due time.

As all accounts of "attraction" which I have seen state that when the $q$ is mated the $\delta \delta$ pay no further attention to her, it seems worth while to offer this experience, which was a surprise also. Caroline G. Soule.

\footnotetext{
***'The note in the last number of Psyche was written subsequently to this and intended as a supplement to it.
} 

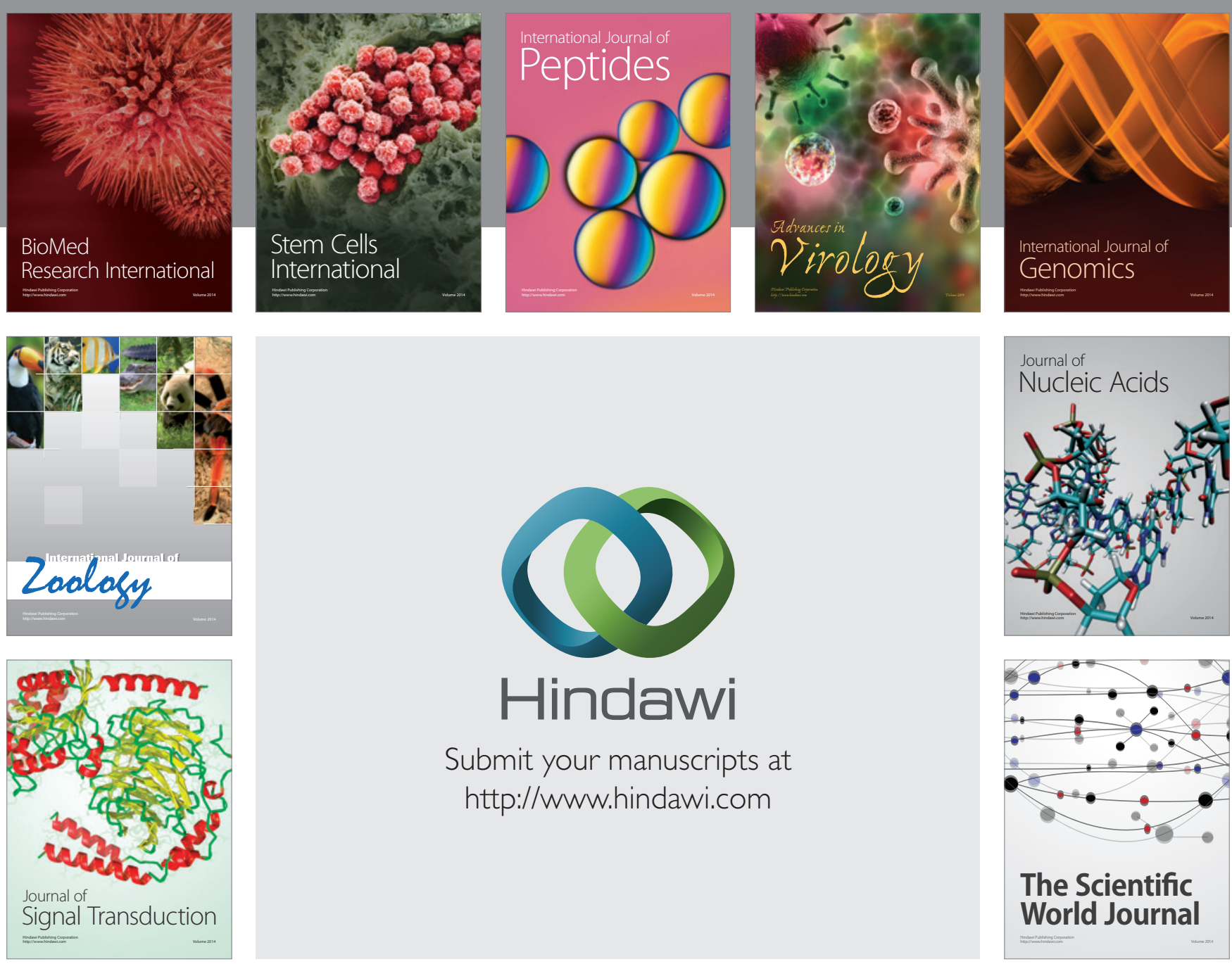

Submit your manuscripts at

http://www.hindawi.com
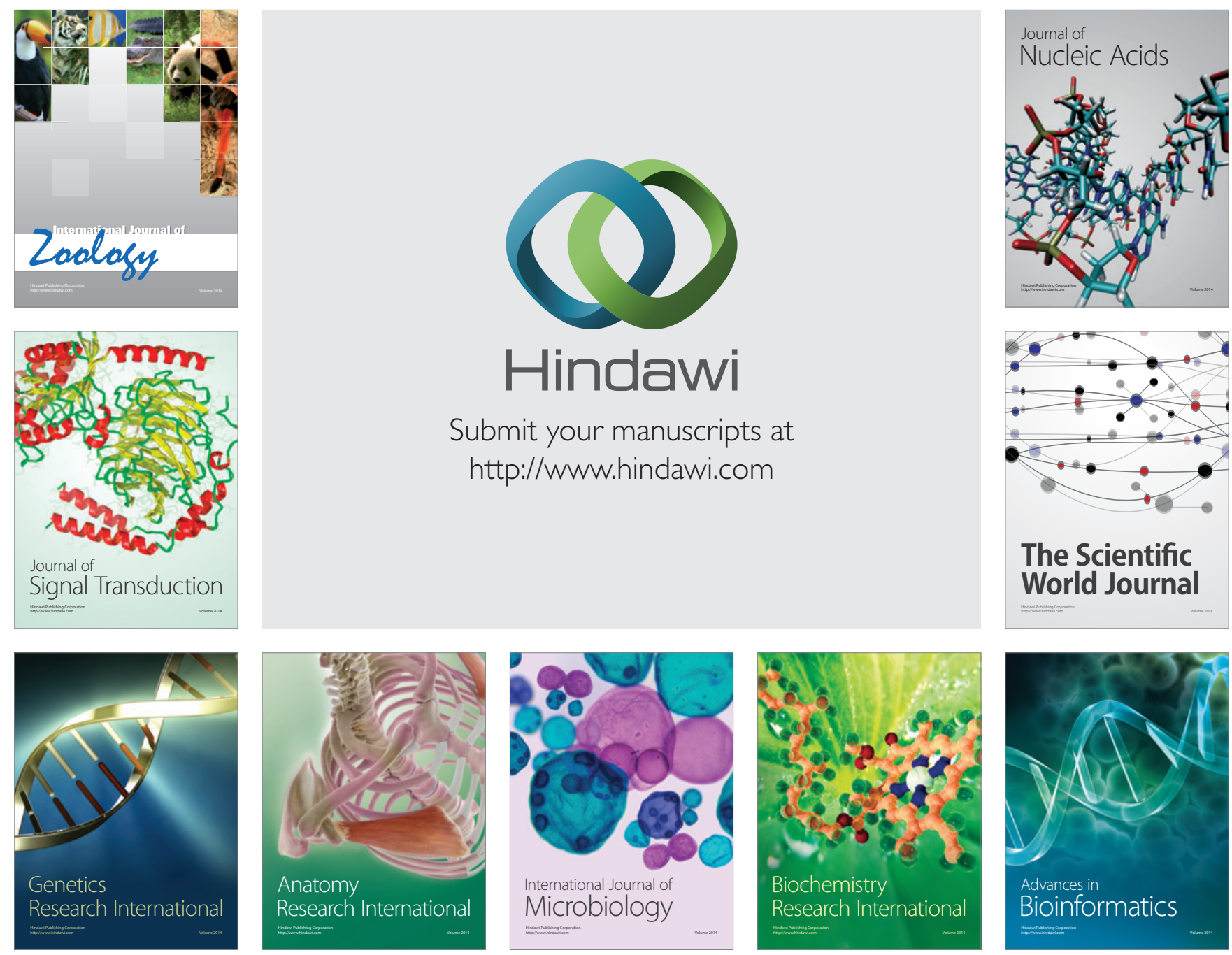

The Scientific World Journal
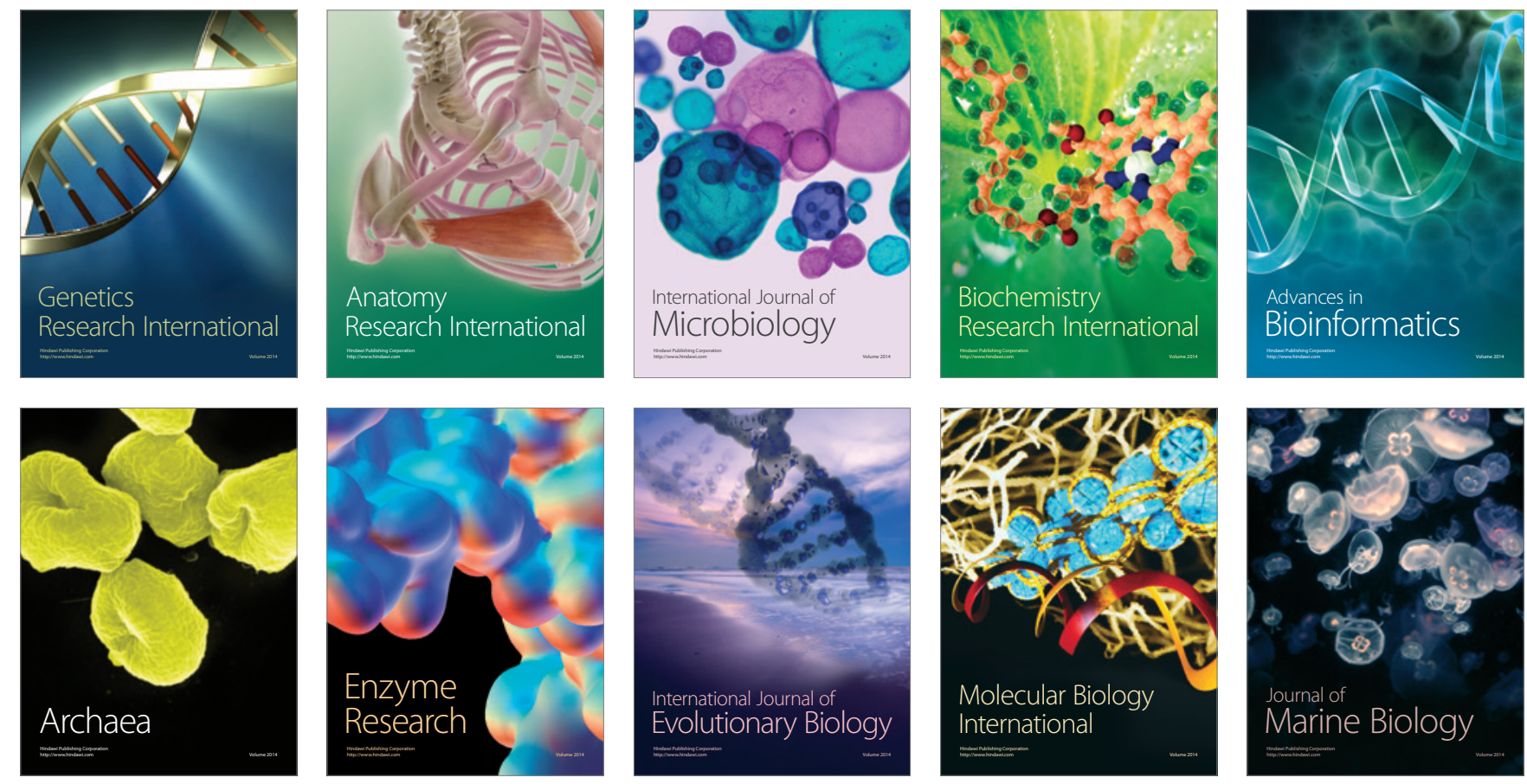